\title{
Effects of Temperature Treatments on the Germination of Taurus Cedar (Cedrus libani A. Rich.) Seeds
}

\author{
Mustafa YILMAZ ${ }^{1}$, Fatih TONGUC ${ }^{2 *}$ \\ ${ }^{1}$ KSU, Faculty of Forestry, Dept. of Forestry Engineering, Kahramanmaras/TURKEY \\ ${ }^{2}$ SDU, Faculty of Forestry, Dept. of Forestry Engineering, Isparta/TURKEY \\ Received (Geliş Tarihi) : 12.12.2013 \\ Accepted (Kabul Tarihi) : 25.11.2014
}

\begin{abstract}
Taurus cedar (Cedrus libani A. Rich.) is one of the most important tree species in Turkey. The current research was conducted to determine the effect of temperature on the germination of $C$. libani seeds. The seeds were collected from five provenances and prechilled for 4 weeks before the germination tests. Germination tests were conducted at six different temperatures $\left(4,8,12,16,20,24^{\circ} \mathrm{C}\right)$. Temperature treatments were found to be effective on the germination percentage and mean germination time. The highest and the lowest average germinations were obtained at the $4^{\circ} \mathrm{C}(55.1 \%)$ and $24^{\circ} \mathrm{C}(26.5 \%)$, respectively. Mean germination time greatly differed at various temperature regimes. In general, the germination decreased with the increased constant temperatures used in the tests. There were also differences between provenances in terms of germination percentages.
\end{abstract}

Key words: Cedrus libani, Taurus cedar, dormancy, germination, prechilling

\section{Farkı Sıcaklık Uygulamalarının Toros Sediri (Cedrus libani A. Rich.) Tohumlarının Çimlenmesi Üzerine Etkileri}

Özet: Toros sediri (Cedrus libani A. Rich.) Türkiye'deki en önemli ağaç türlerinden biridir. Bu araştırmada, Toros sediri tohumlarının farklı sıcaklıklardaki çimlenme tutumlarının belirlenmesi amaçlanmışıtır. Tohumlar beş farklı orijinden toplanmış ve çimlenme testlerinden önce 4 hafta süre ile soğuk katlamaya alınmıştır. Çimlenme testleri altı farklı sıcaklıkta $\left(4,8,12,16,20\right.$, ve $\left.24^{\circ} \mathrm{C}\right)$ gerçekleştirilmiş̧tir. Çimlenme sıcaklı̆̆ı, çimlenme yüzdesi ve ortalama çimlenme süresi üzerinde etkili olmuştur. En yüksek ve en düşük çimlenmeler sırasıyla $4^{\circ} \mathrm{C}(55.1 \%)$ ve $24^{\circ} \mathrm{C}$ (26.5\%) sıcaklıklarda tespit edilmiştir. Ortalama çimlenme süresi büyük ölçüde çeşitli sıcaklık rejimlerinde farklılık göstermiş̧ir. Genel olarak, çimlenme testlerinde kullanılan sicaklık dereceleri arttıkça çimlenmeler azalmıştır. Çimlenme yüzdelerinde orijinlere gore de farklılıklar ortaya çıkmıştır.

Anahtar Sözcükler: Cedrus libani, Toros sediri, dormansi, çimlenme, soğuk katlama

\section{INTRODUCTION}

The genus Cedrus, belongs to family of Pineacea, is represented with four species namely; $C$. deodora Loud. (Nepal and Himalaya Mountains), C. brevifolia Hen. (Cyprus), C. atlantica Manettii (Atlas Mountains) and C. libani A. Rich. (Turkey, Lebanon and Syria) (Vidakovic, 1982; Yaltırı, 1993; Pijut, 2008). Cedrus libani, Taurus cedar, is commonly found over Taurus Mountains in Southern Turkey and has small scattered and degraded populations in Lebanon and Syria (Dirik, 2002; Boydak and Çalıkoğlu, 2008; Hajar et al., 2010). The species grows to old ages and impressive sizes. Its height is usually around $30-40 \mathrm{~m}$ and can reach up to 46 $\mathrm{m}$ and $2.49 \mathrm{~m}$ diameter at breast height (Rushforth, 1987; Boydak, 1996). The tree mainly found on sunny southern slopes in bare karstic lands of the Mediterranean side of Taurus Mountains where it receives moist winds from the sea and grows from 500 $\mathrm{m}$ to $2400 \mathrm{~m}$ above sea level (Atalay 1987). It has a conical form when young, but at later ages, the growth rate slows down and upper branches enlarge to more coarse-branched, flat topped and interesting crown appearance (Chaney, 1993).

C. libani is a wind-pollinated tree. Male flowers appear in July and elongate 3-5 cm in August, while female flowers can be observed early September or
October depending on the location. Cones shed pollen in the late autumn. Cones are barrel shaped, broadest at one-third and taper to apex, grey-green, lumpy, somewhat resinous, $8-12 \mathrm{~cm}$ by $4-6 \mathrm{~cm}$. Scales are usually $5 \mathrm{~cm}$ wide (Boydak and Çalıkoğlu 2008).

In recent decades, there is an increasing interest in using native local trees for reforestation and urban plantings (Ürgenç, 1998; Mansurian et al., 2010). C. libani, throughout its natural distribution, covers an area of over 463.521 ha in Turkey (OGM, 2012). The species is used for afforestation of degraded areas due to its drought resistance (Ducrey, 1993; Boydak, 2003) high survival rate, adaptation, and wood chracteristics in Turkey and in other countries (Fusaro 1990; Morandini and Mercurio 1990; Assadollahi and Hedayeti 1990; Boydak 1996). Moreover, in some intensive plantations take place on fertile soils with $C$. libani outside its natural range (Boydak 1996). C. libani exhibits considerable variation in various form and growth characteristics within its altitudinal and horizontal distribution range. The use of appropriate seed sources for the specific areas affects afforestation and reforestation success (Tilki and Dirik 2007; Boydak and Çalıkoğlu 2008).

Temperature is one of the most effective factors on the germination behavior of seeds (Bewley and Black 
1994; Schmidt 2000). The temperature requirements for seed germination varies by species, variety, and sometimes, populations used as seed sources. Optimum temperature range for germination is also related to the ecology of the seed collection location (Baskin and Baskin 1998; Fenner and Thompson 2005). C. libani seeds exhibit seed dormancy and significant interactions were observed between stratification and seed collection sites (Odabaşı, 1990). Therefore, the investigation of the adaptive mechanisms regarding seed germination is of great importance to conservation and regeneration of $C$. libani in the Mediterranean ecosystems. Detailed studies have been needed on the germination behaviour of $C$. libani seeds at different temperatures.

The aim of this study was to evaluate the effect of different temperature regimes on the germinability and germination speed of $C$. libani seeds collected from five different provenances.

\section{MATERIALS and METHODS}

\section{Seed Material}

The seeds of $C$. libani were collected from five provenances in southern Turkey (Table 1) at the first week of November 2007. In the laboratory, seeds were air-dried until they reached about $6 \%$ moisture content (MC).

Table 1. Location and elevation of populations used as seed sources in the study

\begin{tabular}{|l|c|c|c|}
\hline \multicolumn{1}{|c|}{ Provenance } & Latitude & Longitude & Elevation $(\mathrm{m})$ \\
\hline Göksun & $38^{\circ} 07^{\prime}$ & $36^{\circ} 25^{\prime}$ & 1570 \\
\hline Tarsus & $37^{\circ} 10^{\prime}$ & $34^{\circ} 28^{\prime}$ & 1450 \\
\hline Silifke & $36^{\circ} 44^{\prime}$ & $33^{\circ} 56^{\prime}$ & 1400 \\
\hline Anamur-Abanoz & $36^{\circ} 19^{\prime}$ & $32^{\circ} 57^{\prime}$ & 1480 \\
\hline Isparta-Belceğiz & $38^{\circ} 00^{\prime}$ & $31^{\circ} 16^{\prime}$ & 1420 \\
\hline
\end{tabular}

\section{Germination Temperature}

C. libani seeds have physiological dormancy and they need approximately 4 weeks of prechilling before the germination test (Odabaş1, 1990). In order to determine the effect of temperature on the germination response, seeds from 5 different provenances (Göksun, Tarsus, Silifke, Anamur, Isparta) were prechilled without media for 4 weeks in a fridge $\left(4^{\circ} \mathrm{C}\right)$. Prechilling was applied in the plastic bottles covered with perforated aluminum folio under dark conditions. To keep the level of seed moisture content at maximum level during the prechilling, distilled water was sprayed on the seeds once in every two week period throughout the study.

After the prechilling treatment, the seeds were subjected to germination test at six different constant temperature $\left(4,8,12,16,20\right.$ and $\left.24{ }^{\circ} \mathrm{C}\right)$ regimes. The seeds were rinsed with sterile distilled water for a minute and three replications of 50 seeds were used in the germination tests. During the germination tests, seeds were kept at dark for about $16 \mathrm{~h}$ and under light for $8 \mathrm{~h}$. Germination tests were carried out on two layers of filter paper in $15 \mathrm{~cm}$ petri dishes. Filter papers were changed if any fungal development was observed. Seeds were considered germinated when their radicles protruded $3 \mathrm{~mm}$ and showed geotropism. The Petri dishes were checked every four days at 4 and $8{ }^{\circ} \mathrm{C}$ and every two days at $12,16,20$, and $24{ }^{\circ} \mathrm{C}$, the germinated seeds were counted and removed. Germination tests were terminated after 56 days at 4 and $8{ }^{\circ} \mathrm{C}$ and after 28 days at other temperatures.

To check the interaction between the prechilling and germination temperature, both fresh and prechilled (4 w) seeds of Tarsus provenance were taken to germination tests. The seeds of Tarsus provenance was only used in this test due to the limited amount of seeds from the other provenances.

\section{Germination Parameters}

In the germination tests, germination percentage (GP) and mean germination time (MGT) were calculated according to the following formulas (Bewley and Black 1994):

$$
G P(\%)=\frac{\sum n_{i}}{N} x 100
$$

Where GP (\%) is the germination percentage, $\mathrm{n}_{\mathrm{i}}$ is the number of germinated seeds at day $\mathrm{i}$, and $\mathrm{N}$ is the total number of incubated seeds per test.

$$
M G T=\frac{\sum\left(t_{i} \cdot n_{i}\right)}{\sum n_{i}}
$$

Where MGT is the mean germination time,

$t_{i}$ is the number of days from the beginning of the test, and $n_{i}$ is the number of germinated seeds recorded on day $\mathrm{t}_{(\mathrm{i})}$.

\section{Statistical Analyses}

Germination Percentage (GP \%) and Mean Germination Time (MGT) values of treatments were subjected to factorial ANOVA to detect the significance of germination temperatures and provenances. GP (\%) values was transformed using arcsine $\sqrt{\%}$ formula to normalize error distribution prior to variance analyses. When a significant effect was detected, differences among the groups were identified using Duncan's New Multiple Range test.

\section{RESULTS}

The results of this study revealed that germination temperature and provenance had significant effect on the germination percentage. GP for temperature $\mathrm{x}$ provenance interaction was also significant (Table 2). 
Table 2. Temperature and provenance effect on germination percentage (GP) and mean germination time (MGT)

\begin{tabular}{|c|c|c|c|c|c|c|c|}
\hline \multirow[b]{2}{*}{ Source } & \multirow[b]{2}{*}{ df } & \multicolumn{3}{|c|}{ GP (\%) } & \multicolumn{3}{|c|}{ MGT (day) } \\
\hline & & MS & $\mathrm{F}$ & P-value & $\mathrm{MS}$ & $\mathrm{F}$ & P-value \\
\hline Temperature $(\mathrm{T})$ & 5 & 629.2 & 85.3 & 0.000 & 437.4 & 794.4 & 0.000 \\
\hline Provenance $(\mathrm{P})$ & 4 & 352.5 & 47.8 & 0.000 & 133.3 & 242.1 & 0.000 \\
\hline $\mathrm{T} \times \mathrm{P}$ & 20 & 37.7 & 5.1 & 0.000 & 12.3 & 23.3 & 0.000 \\
\hline Error & 60 & 7.4 & & & 0.55 & & \\
\hline
\end{tabular}

GPs (\%) varied depending on the temperature treatments and were the highest at the $4{ }^{\circ} \mathrm{C}$ constant temperature (Figure 1). GPs were also relatively high at lower temperatures of $8{ }^{\circ} \mathrm{C}$ and $12{ }^{\circ} \mathrm{C}$ temperatures. The average GPs decreased as temperature increased and was the lowest at $24^{\circ} \mathrm{C}$. GPs decreased especially from
$16{ }^{\circ} \mathrm{C}$ through $24{ }^{\circ} \mathrm{C}$. Overall average GPs at $16^{\circ} \mathrm{C}$, $20^{\circ} \mathrm{C}$ were also significantly lower than those of $4{ }^{\circ} \mathrm{C}$, $8^{\circ} \mathrm{C}$ and $12{ }^{\circ} \mathrm{C}$. GPs differed according to provenances as well. Average GP of Isparta and Silifke was significantly higher than those of others (Table 3 ).

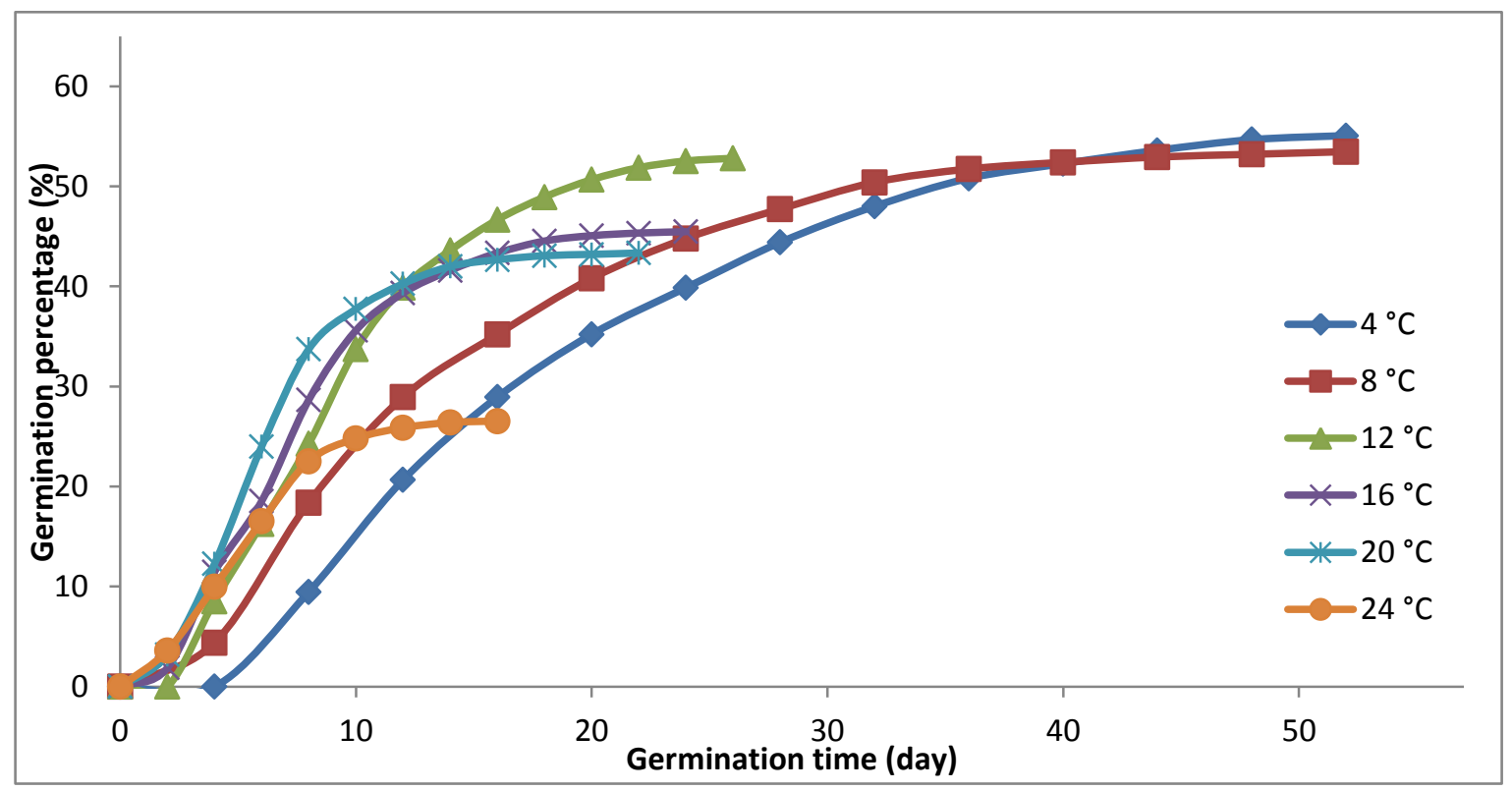

Figure 1. Average germination percentage of seeds at different temperature regimes collected from five provenances

Table 3. Germination percentage of seeds at different temperature regimes

\begin{tabular}{|l|c|c|c|c|c|c|c|}
\hline \multirow{2}{*}{ Provenance } & \multicolumn{9}{|c|}{ Germination percentage (\%) } & \multirow{2}{*}{ Average $^{2}$} \\
\cline { 2 - 7 } & $\mathbf{4}^{\circ} \mathrm{C}$ & $\mathbf{8}{ }^{\circ} \mathrm{C}$ & $\mathbf{1 2}{ }^{\circ} \mathrm{C}$ & $\mathbf{1 6}{ }^{\circ} \mathrm{C}$ & $\mathbf{2 0}{ }^{\circ} \mathrm{C}$ & $\mathbf{2 4}^{\circ} \mathrm{C}$ & \\
\hline Göksun & $51.3 \mathrm{a}$ & $52.7 \mathrm{a}$ & $48.7 \mathrm{a}$ & $46.0 \mathrm{a}$ & $46.7 \mathrm{a}$ & $31.3 \mathrm{~b}$ & $46.1 \mathrm{~B}$ \\
\hline Tarsus & $54.0 \mathrm{a}$ & $51.3 \mathrm{a}$ & $49.3 \mathrm{a}$ & $28.7 \mathrm{~b}$ & $28.7 \mathrm{~b}$ & $14.7 \mathrm{c}$ & $37.8 \mathrm{C}$ \\
\hline Silifke & $56.7 \mathrm{a}$ & $57.3 \mathrm{a}$ & $60.7 \mathrm{a}$ & $58.0 \mathrm{a}$ & $53.3 \mathrm{a}$ & $28.7 \mathrm{~b}$ & $52.4 \mathrm{~A}$ \\
\hline Anamur & $51.3 \mathrm{a}$ & $52.7 \mathrm{a}$ & $50.0 \mathrm{a}$ & $35.3 \mathrm{~b}$ & $31.3 \mathrm{~b}$ & $18.7 \mathrm{c}$ & $39.9 \mathrm{C}$ \\
\hline Isparta & $62.0 \mathrm{a}$ & $53.3 \mathrm{a}$ & $55.3 \mathrm{a}$ & $59.3 \mathrm{a}$ & $56.7 \mathrm{a}$ & $39.3 \mathrm{~b}$ & $54.3 \mathrm{~A}$ \\
\hline Average & $55.1 \mathrm{a}$ & $53.5 \mathrm{a}$ & $52.8 \mathrm{a}$ & $45.5 \mathrm{~b}$ & $43.3 \mathrm{~b}$ & $26.5 \mathrm{c}$ & \\
\hline
\end{tabular}

${ }^{1}$ The values on the same line followed by the same letters are not significantly different at $\mathrm{P}<0.05$.

${ }^{2}$ The values on the same column followed by the same capital letters are not significantly different at $\mathrm{P}<0.05$.

MGT significantly differed at various temperature regimes. Germination accelerated with an increase in constant temperatures from $4^{\circ} \mathrm{C}$ through $24^{\circ} \mathrm{C}$ (Table 4). Mean germination time was lowest at $4^{\circ} \mathrm{C}$ in all the provanances. There was also statistically important differences for the average MGT between provenances. Göksun provenance was clearly the fastest at different temperatures in terms of germination speed. 
Table 4. Mean germination time of seeds at different temperature regimes

\begin{tabular}{|c|c|c|c|c|c|c|c|}
\hline \multirow{2}{*}{ Provenance } & \multicolumn{6}{|c|}{ Mean germination time (days) } & \multirow{2}{*}{ Average } \\
\hline & $4^{\circ} \mathrm{C}$ & $8^{\circ} \mathrm{C}$ & $12^{\circ} \mathrm{C}$ & $16^{\circ} \mathrm{C}$ & $20^{\circ} \mathrm{C}$ & $24^{\circ} \mathrm{C}$ & \\
\hline Göksun & $13.9 \mathrm{~d}^{1}$ & $8.6 \mathrm{c}$ & $6.0 \mathrm{~b}$ & $5.4 \mathrm{ab}$ & $5.3 \mathrm{a}$ & $4.8 \mathrm{a}$ & $7.3 \mathrm{~A}^{2}$ \\
\hline Tarsus & $24.8 \mathrm{f}$ & $22.8 \mathrm{e}$ & $12.9 \mathrm{~d}$ & $9.7 \mathrm{c}$ & $8.2 \mathrm{~b}$ & $6.1 \mathrm{a}$ & $14.1 \mathrm{D}$ \\
\hline Silifke & $21.5 \mathrm{~d}$ & $17.7 \mathrm{c}$ & $11.8 \mathrm{~b}$ & $10.2 \mathrm{~b}$ & $7.3 \mathrm{a}$ & $7.9 \mathrm{a}$ & $13.1 \mathrm{C}$ \\
\hline Anamur & $19.3 \mathrm{e}$ & $17.0 \mathrm{~d}$ & $12.0 \mathrm{c}$ & $10.9 \mathrm{~b}$ & $9.0 \mathrm{a}$ & $8.1 \mathrm{a}$ & $12.7 \mathrm{C}$ \\
\hline Isparta & $21.0 \mathrm{e}$ & $14.0 \mathrm{~d}$ & $8.1 \mathrm{c}$ & $6.9 \mathrm{~b}$ & $6.9 \mathrm{~b}$ & $5.0 \mathrm{a}$ & $10.3 \mathrm{~B}$ \\
\hline Average & $20.1 \mathrm{f}$ & $16.0 \mathrm{e}$ & $10.2 \mathrm{~d}$ & $9.0 \mathrm{c}$ & $7.3 \mathrm{~b}$ & $6.4 \mathrm{a}$ & \\
\hline
\end{tabular}

${ }^{1}$ The values on the same line followed by the same small letters are not significantly different at $\mathrm{P}<0.05$.

${ }^{2}$ The average values on the same column followed by the same capital letters are not significantly different at $\mathrm{P}<0.05$.

Both fresh (nonprechilled) and prechilled seeds of Tarsus provenance demonstrated similar germination percentages at $4{ }^{\circ} \mathrm{C}$ and $8{ }^{\circ} \mathrm{C}$. On the other hand, GPs of nonprechilled seeds was significantly lower at 12,16 ,
20 and $24^{\circ} \mathrm{C}$. Germination speed of nonprechilled seeds was also evidently slower than those of prechilled seeds at all the temperatures (Figure 2).

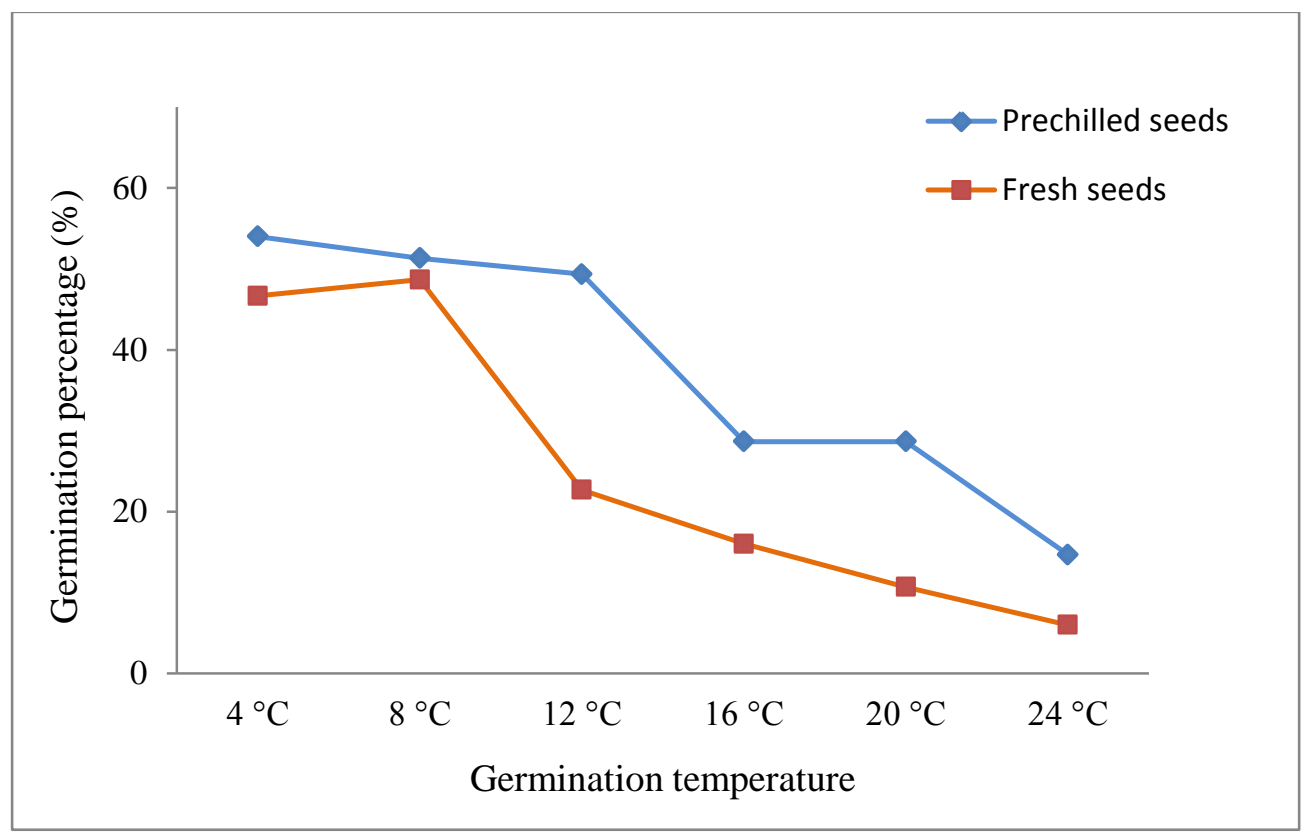

Figure 2. Germination percentages of fresh and prechilled (4 w) seeds from Tarsus provenance at different temperatures

\section{DISCUSSION}

According to the present study, the temperature had the strong effect on the germination of $C$. libani seeds (Table 2, Table 3). Among the tested temperature regimes, $4^{\circ} \mathrm{C}, 8{ }^{\circ} \mathrm{C}$, and $12{ }^{\circ} \mathrm{C}$ constant temperatures appeared to be suitable germination temperatures for the prechilled seeds since the average germination percentages were significantly lower at any other temperature regimes tested during the study. Germination temperatures of 4 and $8{ }^{\circ} \mathrm{C}$ were effective on breaking the dormancy and, thus, appeared to be suitable for germination temperature for fresh seeds. There were great decline in the average germination percentages at $24^{\circ} \mathrm{C}$.
GPs of provenances were similar and about 50-60\% at 4,8 and $12{ }^{\circ} \mathrm{C}$ after prechilling treatment. But, various GPs of provenances observed at 16, 20, and 24 ${ }^{\circ} \mathrm{C}$ were due to probably various dormancy levels and the effect of temperature on various dormancy depths. Four weeks of prechilling was enough for full dormancy removal in Göksun, Silifke, and Anamur seeds and, therefore GPs of those provenances were similar at all the temperatures except $24{ }^{\circ} \mathrm{C}$. On the other hand, GPs of Tarsus and Anamur declined at $16{ }^{\circ} \mathrm{C}$ and above temperatures due to probably more prechilling requirement. The results agree with the author (Odabaş1, 1990), who reported that dormancy on C. libani seeds depend on the seed provenances. On the other hand, it is 
stated (Dirr and Heuser, 1987) that Cedrus spp. seeds has little or no dormancy and can germinate without any pretreatment. The results of this study partly agree with the authors (Dirr and Heuser, 1987). In the present study in which seeds from Tarsus provenance were prechilled significantly affected the seed GP and mean germination time compared to GP and MGT of nonprechilled seeds especially at $12{ }^{\circ} \mathrm{C}$ and above temperatures (Figure 2). Current study demonstrated that $C$. libani seed has variable degree of dormancy and need about $4 \mathrm{w}$ prechilling before germination test.

Germination temperature is found to be very effective on the germination parameters. Different germination temperatures such as constant temperature of $20^{\circ} \mathrm{C}$, (ISTA 1996) and alternating temperature of $25 \sim 20^{\circ} \mathrm{C}, 30 \sim 20^{\circ} \mathrm{C}$ have been used in the germination of pretreated $C$. libani seeds (ISTA, 1996; Takos and Merou, 2001). In the present study, the constant temperature of 4,8 and $12{ }^{\circ} \mathrm{C}$ resulted in higher germination percentages than the tested temperatures of 16,20 and $24{ }^{\circ} \mathrm{C}$ (Table 3). The results of this study imply that the germination temperature of $20{ }^{\circ} \mathrm{C}$ or above is not favorable for prechilled $C$. libani seeds. Considering the overall results, it is indicated that $C$. libani seeds exhibit better germination performance at lower constant temperatures which is somewhat different than seed germination behavior of many woody plant species

Germination temperatures higher than the optimum temperature usually cause secondary dormancy (Khan and Samimy, 1982; Copeland and McDonald, 1999). In the present study, lower germinability observed at $20^{\circ} \mathrm{C}$ and $24{ }^{\circ} \mathrm{C}$ temperatures might be partly the result of secondary dormancy. Similar behavior of secondary dormancy over $20^{\circ} \mathrm{C}$ was also reported for beechnuts (Gugała, 2002; Y1lmaz, 2005) and Fraxinus spp. seeds (Tylkowski, 1988; Piotto and Di noi, 2003) as well. Induction of secondary dormancy in Cedrus spp. was also supported by another study (Zaki, 1970) who reported secondary dormancy phenomenon observed in $C$. atlantica seeds resulted from exposing the seeds to high temperatures.

In the current study, the seeds were stratified at $4{ }^{\circ} \mathrm{C}$ in the fridge for removing the dormancy. Lower germination temperatures such as $8{ }^{\circ} \mathrm{C}$ was also effective in removing the dormancy of fresh seeds of Tarsus provenance, which was supported by several studies (Suszka et al., 1996; Bonner, 2008).The authors (Thapliyal and Gupta 1980) stated that stratification temperature of $9^{\circ} \mathrm{C}$ was also effective in dormancy breaking in Cedar seeds. For nonprechilled seeds, germination temperature of 4 and $8{ }^{\circ} \mathrm{C}$ can be suggested since these temperatures is effective on the dormancy breaking of the seeds (Figure 2). For prechilled seeds, 12 and $16{ }^{\circ} \mathrm{C}$ can be preferred due to high and faster germination.

\section{CONLUSIONS}

This study focused on to determine the effect of temperature on the seed germination of $C$. libani. Seeds were obtained from five provenances and prechilled before the germination tests. The temperature had strong effect on the germination of $C$. libani seeds. Mean germination time greatly differed at various temperature regimes. Germination decreased with the increased constant temperatures used in this study. Seed provenances had also an effect on the final germination percentage. Further research is needed on the seed maturation and collection time, seed storage, and the relationship between collection time and dormancy level in $C$. libani seeds.

\section{REFERENCES}

Assadollahi, F., Hedayeti, M.A. 1990. Cedrus plantation experiments in Iran. Proc of the Int Cedar Symposium, October 22-27, Antalya, Forest Res Ins Press, Ankara. 59:266-272.

Atalay, I. 1987. Sedir ormanlarının yayılış gösterdiği alanlar vey akın çevresinin genel ekolojik özelikleri ile sedir tohum transfer rejyonlaması. OGM Yayın No: 663, Ankara.

Baskin, C.C., Baskin, J.M. 1998. Seeds: Ecology, biogeography and evolution of dormancy and germination. Academic Press, San Diego.

Bewley, J.D., Black, M. 1994. Seeds: Physiology of development and germination. Plenum Press, New York. 445 p.

Bonner, F.T, 2008 Seed Biology, p. 3-37. In: Bonner FT, Nisley RG (Eds.). Woody plants seed manual. USDA Forest Service.

Boydak, M. 1996. Ecology and silviculture of cedar of lebanon (Cedrus libani A. Rich.) and conservation of its natural forests. Turkish Min. of For. Press,Pub. No:12, Ankara.

Boydak, M. 2003. Regeneration of lebanon cedar (Cedrus libani A. Rich.) on karstic lands in Turkey. Forest Ecol and Manag178: 231-243.

Boydak, M., Çalikoğlu, M. 2008. Biology and silviculture of lebanon cedar (Cedrus libani A. Rich.) OGEM-VAK. Press, Ankara. 224 p.

Chaney, W.R. 1993. Cedrus libani, cedar of Lebanon. Arbor Age. 13(1):26-27.

Copeland, L.O., Mcdonald, M.B. 1999.Seed Sci Technol. Kluwer Academic Publishers, Boston.

Dirik, H. 2002. Effet du stress hydrique osmotique sur la germination des graines chez les provenances de Cedre du Liban (Cedrus libani A. Rich.) d'origine turque. Ann. For. Sci. 57:361-367.

Ducrey, M. 1993. Adaptation du Cedre de 1' Alas (Cedrus atlantica Monetti) au climat me'diterrane'en: aspect e'cophysiologiques de sa re'action a' la secheresse. In: M' Hirit, O, Samik A, Malagnoux M (Eds.).Le Ce'dre de 1' Atlas.AnnRech For Marocco 27(1): 140-153. 
Dirr, M.A., Heuser, C.W. 1987. The Reference manual of woody plant propagation. Varsity Press, Athens, GA, USA.

Fenner, M., Thompson, K. 2005. The ecology of seeds. Cambridge Univ. Press, UK.

Fusaro, E. 1990. Characteristics and distribution of cedar afforestations in Italy. Proc of the Int Cedar Symposium, October 22-27, Antalya, Forest Res Ins Press, Ankara. 59:273-285.

Gugała, A. 2002. Changes in quality of beech (Fagus sylvatica L.) seeds stored at the Forest Gene Bank Kostrzyca. Dendrobiology. 47:33-38.

Hajar, L., François, L., Khater, C., Jomaa, I., Deque, M. Cheddadi, R. 2010.Cedrus libani (A. Rich) distribution in Lebanon: Past, present and future. C. R. Biologies, 333:622-630.

ISTA 1996. International rules for seed testing. Seed Sci. Technol. (Supplement), 24:1-335.

Khan, A.A,Samimy, E.C. 1982. Hormones in relation to primary and secondary seed dormancy. p. 203-241. In: Khan AA (Eds.). Physiology and biochemistry of seed development, dormancy and germination. Elsevier, Amsterdam.

Mansurian, S., Vallaurı, D., Dudley,N. 2010. Forest restoration in landscapes: Beyond planting trees Springer.465 p.

Morandini, R.,Mercurio, R.1990. Atlas cedar (Cedrus atlantica Man.) in Italy. Proc of the Int Cedar Symposium, October 22-27, Antalya, Forest Res. Ins. Press, Ankara. 59:302-307.

Odabaşı, T. 1990. Lübnan sediri (Cedrus libani A. Rich.)'nin kozalağı ve tohumunun özellikleri. OGM Eğitim Dairesi, Yayın ve Tanıtma Şube Müdürlüğü, Ankara.

OGM, 2012. Türkiye orman varlığı. OGM Orman İdaresi ve Planlama Dairesi Başkanlığı, Ankara, 27s.

Pijut, P. 2008. Cedrus Tree, p. 357-362. In: Bonner FT, Nisley RG (Eds.).Woody plants seed manual. USDA Forest Service.
Piotto, B., Di Noi, A. 2003. Seed propagation of mediterranean trees and shrubs. ANPA, Roma.

Rushforth, K.D. 1987. Conifers, Facts on file inc., NY, NY. ISBN:0-8160-1735-2.

Schmidt, L. 2000.Guide to handling of tropical and subtropical forest seed. Danida Forest Seed Centre, Denmark.

Suszka, B., Muller, C., Bonnet-Masimbert, M 1996. Seeds of forest broadleaves, from harvest to sowing. INRA, France.

Tilki, F., Dirik, H. 2007.Seed germination of three provenances of Pinus brutia (Ten.) as influenced by stratification, temperature and water stress. J. Environ. Biol., 28(1):133-136.

Takos, I., Merou, T. 2001. Effect of storage and treatment on germination of Cedrus deodara Loud. and Cedrus libani A. Rich. Silvae Genet. 50(56):205- 208.

Tylkowski, T.1988. Storage of stratified seeds of European ash (Fraxinus excelsior L.). Arboretum Kórnickie. 33:259-266.

Thapliyal, R.C., Gupta, B.N. 1980.Effect of seed source and stratification on the germination of deodar seed (Cedar). Seed Sci. Techno., 18:145-150.

Ürgenç, S. 1998. Ağaçlandırma Tekniği. Istanbul Üniv. Orman Fakültesi, Yayınları 3994/441, Istanbul.

Vidaković, M. 1982. Četinjače, morfologija i varijabilnost. Yugoslav Academy of Sciences and Arts, Sveučilišna Naklada Liber, Zagreb.

Yılmaz, M. 2005.Doğu kayını (Fagus orientalis Lipsky.) tohumlarının fizyolojisi üzerine araștırmalar, Doktora Tezi, İstanbul Üniversitesi, Fen Bilimleri Enstitüsü, p. 170

Yaltırik, F. 1993. Dendroloji (Dendrology), Gymnospermae, 2. Bask1. Istanbul Üniversitesi, Orman Fakültesi Yayınları, Istanbul.

Zaki, A. 1970. Preliminary studies on dormancy in cedar seed and the effect of various factors on its germination. Ann. Rech. for Marocco 11:243-298. 